Neuberger, A. \& Webster, T. B. (1945). Biochem. Y. 39, 200.

Roche, J. \& Gueit, M. (1945). C.R. Soc. Biol. Paris, 139, 1 roo.

Roche, A., Roche, J., Drouineau, S. \& Passelaigue, P. (1938). Bull. Soc. Chim. Biol. Paris, 20, 217.

Rosen, F., Huff, J. W. \& Perlzweig, W. A. (1946). F. biol. Chem. 163, 343.

Schweigert, B. S., Sauberlich, H. E., Elvehjem, C. A. \& Baumann, C. A. (1946). J. biol. Chem. 165, 187.

Singal, S. A., Briggs, A. P., Sydenstricker, V. P. \& Littlejohn, J. M. (1946). F. biol. Chem. 166, 573.

Sprince, H. \& Woolley, D. W. (1945). Y. Amer. chem. Soc. 67, 1734 .

Sun, T. P. (1926). Anat. Rec. 34, 341.

\title{
Induced Cobalt Deficiency in Lambs
}

\author{
BX J. STEWART \\ Moredun Institute, Gilmerton, Edinburgh
}

(Received 13 December 1950)

The object of the experiments described below was to induce cobalt deficiency in lambs by giving a diet composed of foodstuffs sufficiently remote from pasture to avoid the criticism that some unknown pasture factor other than cobalt might be involved in the causation of the marasmus, now called 'cobalt deficiency', and to prove conclusively that a lack in the diet of cobalt per se is responsible for 'pining' in lambs.

First experiment, 1946

\section{EXPERIMENTAL}

Basic ration. The basic daily ration used was $\mathrm{I} 100 \mathrm{~g}$. flaked maize, $25^{\circ} \mathrm{g}$. hay and $60 \mathrm{~g}$. of a mineral mixture composed of ground limestone, steamed bone-flour and crude rock salt. The introduction of hay was necessary to ensure that the rumen processes would be normal, as it was not considered satisfactory to use wood pulp or a similar source of cellulose, since it might cause upsets in rumination, regarding which little is known. The hay was kept to a minimum (250 g./day) and was obtained from a field of which the soil was deficient in cobalt.

The diet was adequate in starch and protein equivalent for a pregnant or lactating ewe. According to Woodman (1948), a $120 \mathrm{lb}$. ewe requires $10 \mathrm{lb}$. starch equivalent (S.E.)/week for maintenance and $4 \mathrm{lb}$. starch equivalent (S.E.)/week/gal. milk; and $0.46 \mathrm{lb}$. protein equivalent (P.E.)/week for maintenance and $\mathrm{x}$ lb. protein equivalent (P.E.)/week/gal. milk. The starch equivalents of the flaked maize and hay were 84 and 30 respectively, and the protein equivalents were about ro and 3 . Thus the diet outlined above supplied the energy requirements for maintenance and for at least I gal. weckly of milk, the average weight of the ewes being i $5 \mathrm{lb}$.

The cobalt content of the ration was assayed spectrographically with the following result:

$$
\begin{array}{ll}
\text { Flaked maize } & 0.025 \text { p.p.m. } \\
\text { Hay } & 0.10 \text { p.p.m. } \\
\text { Mineral mixture } & 0.27 \text { p.p.m. }
\end{array}
$$


Thus the daily intake of cobalt/ewe was about $0.0687 \mathrm{mg}$. Little is known of the daily requirements of sheep for cobalt. Australian research workers (Filmer \& Underwood, 1937) have reported cure and prevention of cobalt deficiency by dosing with as small an amount of cobalt as $0.1 \mathrm{mg}$./day. The cobalt content of the Scottish pastures on which lambs pine ranges from 0.10 to 0.03 p.p.m. (Stewart, Mitchell \& Stewart, 194I), and if lambs eat as much as $2.5 \mathrm{lb}$. dry matter daily they would be ingesting $0.1135^{-0} 034 \mathrm{mg}$. cobalt. It was considered possible that the experimental diet containing $0.0687 \mathrm{mg}$./day might be low enough to produce pine in lambs.

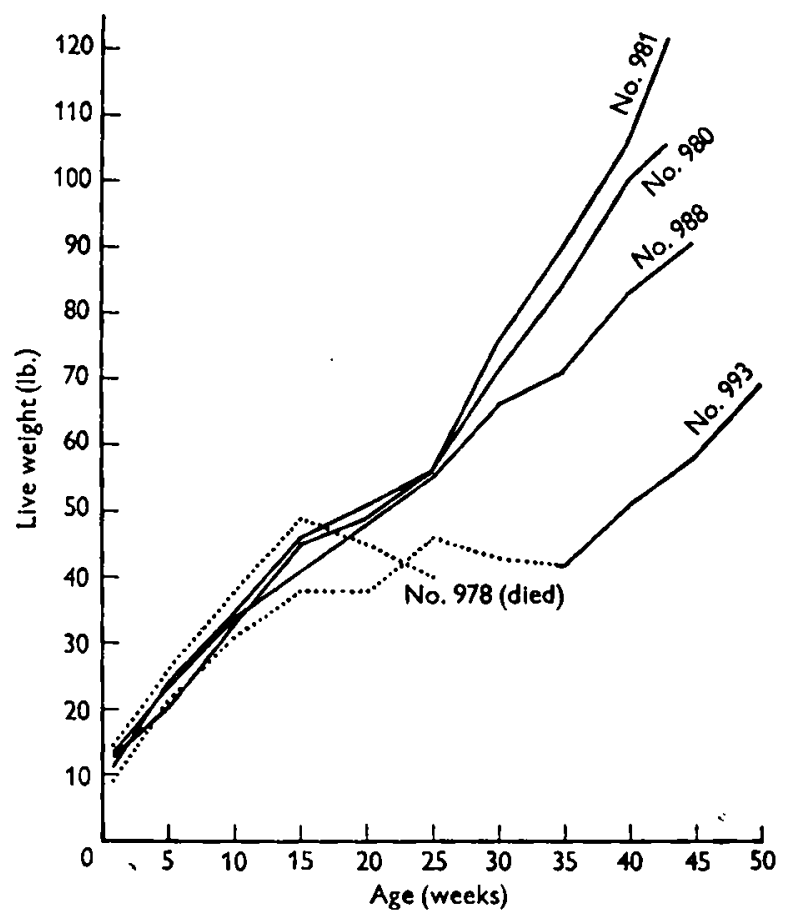

Fig. I. Live-weight curves of lambs in the 1946 experiment. - , lambs receiving cobalt-deficient diet and a cobalt supplement; ...... lambs receiving cobalt-deficient diet only.

Sheep. On I January 1946 nine in-lamb ewes were divided into three equal groups and placed in boxes with cement floors covered with peat-moss litter. They were fed the above ration, but each member of one group received weekly ro mg. of cobalt, as cobalt chloride.

'The ewes ate the ration readily, but several deaths occurred during the last week of pregnancy due to 'lambing sickness', probably brought about by the nature of the diet, highly digestible flaked maize, and by the lack of exercise due to restraint of the stalls.

Lambs. There were eventually on experiment five lambs, three, nos. 980, $98 \mathrm{I}$ and 988, from control ewes receiving the diet and ro mg. cobalt/week and two, nos. 978 and 993 , from the ewes receiving the diet only. Nos. $980,98 \mathrm{I}$ and 988 received $10 \mathrm{mg}$. cobalt/week from birth and, when weaned at to weeks of age, were given $800 \mathrm{~g}$. 
flaked maize, $80 \mathrm{~g}$. hay and $25 \mathrm{~g}$. mineral mixture daily, which supplied $0.0347 \mathrm{mg}$. cobalt. The ration was steadily increased till at 16 weeks of age the lambs were being offered the full amount given to their mothers. This appeared to be the limit of appetite and occasionally food was left uneaten, so that the cobalt ingested from the diet was never above $0.0687 \mathrm{mg}$./day.

\section{Further experiments, $1947^{-8}$}

Basic ration. The basic ration was the same as in the first experiment.

Despite the foodstuffs being from new sources the cobalt content was still about $0.0687 \mathrm{mg}$./day, compensation for any increase in the cobalt content of the feedingstuffs being made by altering slightly the amount of mineral mixture fed. Several of the ewes died of 'lambing sickness' in both years, but in similar experiments in 1949 and 1950, when great care was taken to exercise the ewes once a week by allowing them to run in concrete yards, no deaths occurred, the ewes all remaining healthy and lambing successfully. It is concluded that in the previous years the deaths in ewes on this diet were caused by the enforced lack of exercise rather than by the composition of the ration. Several lambs died in both 1947 and 1948 in the neonatal stage from a pyaemia caused by a staphylococcal infection.

Lambs. Lambs nos. 334, 338, 339, 340, 768, 789 and 806 were from ewes receiving cobalt supplement and lambs nos. $335,336,345,785,787,788,800$ and 816 were from ewes receiving the diet only.

Lamb no. 8I6 within a few days after birth showed signs of a staphylococcal infection, and shortly afterwards its mother died. From this stage it was raised on cow's milk and transferred to the control group receiving io mg. cobalt weekly after the 3 rd week of life.

The lambs were managed exactly as in 1946 but fed individually.

\section{RESULTS}

First experiment, 1946. Lambs nos. 980, 981 and 993, receiving $10 \mathrm{mg}$. cobalt/week, made steady gains in weight, as seen in Fig. I. 'Their live-weight curves correspond to those of lambs on good pasture. Lambs nos. 978 and 993 were offered the same diet as the others, and it will be seen from Fig. I that they showed similar weight gains until about the $14^{\text {th }}$ week of age, no. $97^{8}$ being the heaviest of all the five lambs at that age. From the $15^{\text {th }}$ week no. 978 began to lose weight steadily and died at the $25^{\text {th }}$ week, showing all the symptoms of cobalt deficiency and weighing only $38 \mathrm{lb}$. The weight of no. 993 from the age of 14 weeks fluctuated round $40 \mathrm{lb}$. and at $3 \mathrm{r}$ weeks was only $46 \mathrm{lb}$., as compared with 66,72 and $75 \mathrm{lb}$. for nos. $980,98 \mathrm{r}$ and 988 respectively. From this age no. 993 was dosed with $10 \mathrm{mg}$. cobalt weekly. Its weight, after falling for the Ist week, rose steadily and at 48 weeks of age was $68 \mathrm{lb}$., an increase of $27 \mathrm{lb}$. in 17 weeks, the live-weight curve being parallel to that of the control lambs.

Lambs nos. 978 and 993 had smaller appetites than the controls. 'They were continually leaving food, and various methods were tried to persuade them to eat more. Neither ever ate the full ration of flaked maize, hay and mineral mixture, so that their 
cobalt intake was always less than $0.0687 \mathrm{mg}$./day. When lamb no. 993 was given cobalt at $3 \mathrm{I}$ weeks old it began to eat its ration more quickly, but even at 48 weeks it still left a quantity in the feeding trough.

Further experiments, 1947-8. The live-weight curves of the lambs, with the exception of nos. 787 and 788 , are shown in Fig. 2. Lamb no. 816 made little progress for the first 10 weeks but from that age made normal live-weight gains, reaching $75 \mathrm{lb}$. at the $35^{\text {th }}$ week. Lamb. no. 340, which had never made normal live-weight gains, died at 18 weeks of age. A post-mortem examination failed to reveal the cause of death.

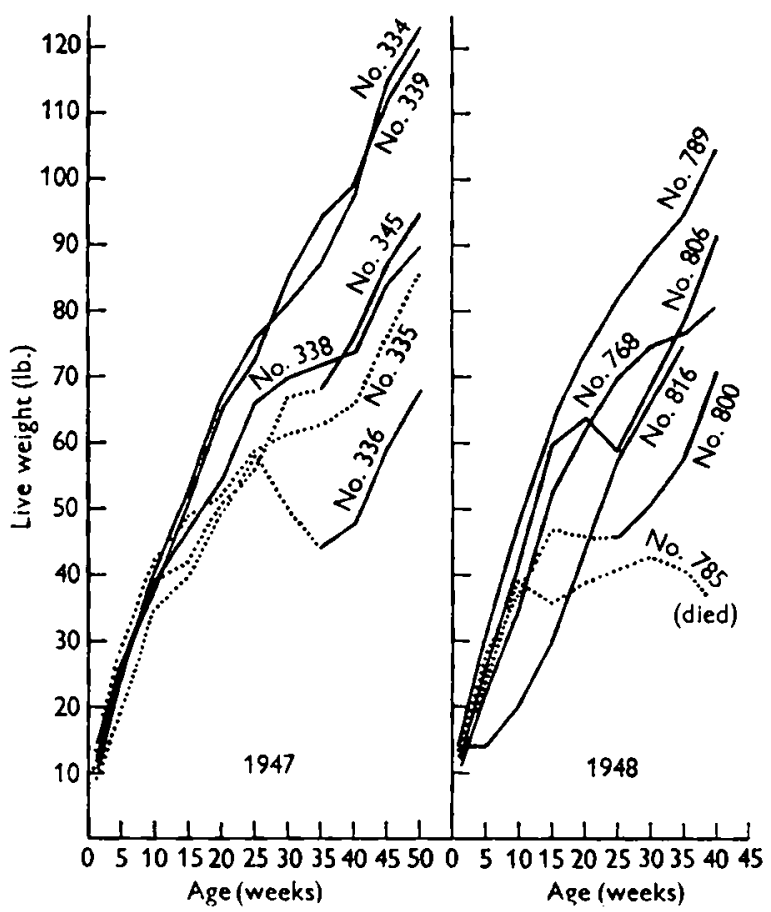

Fig. 2. Live-weight curves of lambs in the 1947 and 1948 experiments. ___, lambs receiving cobalt-deficient diet and a cobalt supplement; ....., lambs receiving cobalt-deficient diet only.

All the control lambs receiving $10 \mathrm{mg}$. cobalt/week from birth made normal liveweight gains, with the exception of no. 338 which weighed only $74 \mathrm{lb}$. at the 4 oth week. Lamb no. 806 fluctuated in weight after the $15^{\text {th }}$ week, but by the $25^{\text {th }}$ week resumed gaining weight in a normal manner. The lambs on deficient diet only showed the effects of this diet at the ${ }_{15}{ }^{\text {th }}$ week. Lamb no. 785 continued on the deficient diet, but died at the $3^{8 \text { th }}$ week with all the clinical symptoms of cobalt deficiency and weighing only $38 \mathrm{lb}$. The other lambs in this group received cobalt at different stages once they had obviously shown that their weight curves were on the decline, and immediately made spectacular increases in weight. Anomalous behaviour was shown by lamb no. 335. This animal at 25 weeks of age weighed only $60 \mathrm{lb}$. and appeared likely to become a typical case of cobalt deficiency if left on the deficient diet. No cobalt was given but, despite this, it began to gain weight and at 50 weeks of age 
weighed $85 \mathrm{lb}$. There is no accountable reason for this behaviour of no. 335 except that the diet of $0.0687 \mathrm{mg}$. cobalt must be near the margin of adequacy and that for exceptional animals this amount is sufficient to allow them to keep their appetite and so maintain, or even gain, weight.

Lambs nos. 787 and 788 were twin lambs of a ewe on the deficient diet only. Their weight curves are shown in Fig. 3 .

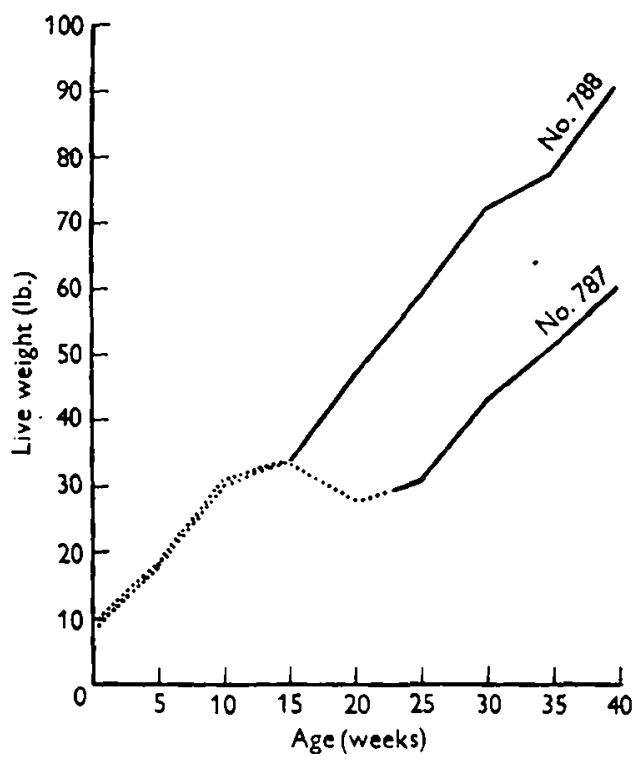

Fig. 3. Live-weight curves of twin lambs nos. 787 and 788 . __. receiving cobalt-deficient diet and a cobalt supplement; ....., receiving cobalt-deficient diet only.

They made identical weight gains till 15 weeks of age, when each weighed $34 \mathrm{lb}$. At this age no. 788 received $10 \mathrm{mg}$. cobalt weekly and increased its weight by $21 \mathrm{lb}$. in 8 weeks, whereas no. 787 , receiving no cobalt, lost $6 \mathrm{lb}$. in the same period. At the $23^{\text {rd }}$ week no. 787 was also given cobalt at the rate of $10 \mathrm{mg}$. weekly and in the next 17 weeks added $32 \mathrm{lb}$. to its weight, whilst no. 788 added $35 \mathrm{lb}$.

\section{DISCUSSION}

Three postulates must be fulfilled to justify the statement that a deficiency of a particular constituent of the diet is the cause of a definite disease syndrome in a certain species of animal.

(I) It should be possible to correlate every case of the disease with a real deficiency of the particular constituent in the diet under consideration.

(2) Addition of the particular constituent to the deficient diet should cure or prevent the disease.

(3) The disease condition should be capable of induction in healthy animals by the feeding of an artificial diet, adequate in every essential constituent except the particular constituent, which should be of a content comparable to that in the diet of naturally occurring cases of the disease. 
Of these postulates, no. 3 has been often ignored of recent years, with the result that we are still in doubt regarding the causal role of many dietary constituents in wellestablished disease syndromes, and this is especially so with regard to the trace elements. It is not sufficient to use the criterion of (I) low intake, (2) depletion of the animal, as shown by tissue analysis, and (3) dramatic response after addition of a constituent to the diet or by injection of the animal, since the interrelationships of trace elements one with another have confused the true significance of the part played by several trace elements in disease syndromes, e.g. copper and molybdenum in 'teart' disease, copper and cobalt in 'coast' disease and the anomalous position of copper in the prevention of swayback in lambs in Great Britain, which usually occurs on pastures of normal copper content.

Several Australian workers (Marston, 1949) have produced the syndrome of cobalt deficiency by cutting herbage from a suspected cobalt-deficient area and feeding it to sheep kept indoors, and Bowstead and his colleagues in Canada (Bowstead \& Sackville, 1939; Bowstead, Sackville \& Sinclair, 1941-2), by maintaining sheep on a basal diet of non-leguminous hay and ground oats, reproduced a condition of unthriftiness which, after many curative attempts with a large number of substances, all without real effect, responded to cobalt therapy, but again the foodstuffs fed were all harvested off the suspected soil. Therefore neither of the above types of investigation fulfils postulate no. 3 , since the ration used does not rule out the presence of some still unknown factor causing the physiological upset curable by cobalt supplements, similar to the action of copper in preventing molybdenum poisoning in 'teart' disease.

The experiments described in this paper therefore were attempts to fulfil the third postulate as far as cobalt deficiency was concerned as a causal factor of 'pine' in lambs and, although hay from a cobalt-deficient area was used, it was kept to a minimum, being only one-sixth of the total dry matter fed.

The majority of the experimental animals receiving the basal diet and cobalt made the normal live-weight gains to be expected from the starch equivalent and protein equivalent of the ration, reaching approximately $100 \mathrm{lb}$. live weight in about 40 weeks. Those receiving no cobalt supplement made normal progress till about the Ioth-I 4 th week when they had reached a weight of $40 \mathrm{lb}$., then their weight remained steady or decreased and, if continued on the deficient basal diet, the lambs showed eventually the signs of marasmus identical with that attributed to cobalt deficiency. The liveweight curves of both the control and the experimental animals were very similar to those obtained in experiments carried out in the field (Stewart, 1946). There was a dramatic response with every deficient lamb given cobalt, the two outstanding examples being the twins, nos. 787 and 788 .

It would appear that the diet designed for these experiments which allowed the lambs a maximum cobalt intake of $0.0687 \mathrm{mg}$. $/$ day will produce the symptoms of cobalt deficiency, and that an immediate recovery response is obtained by allowing the marasmic lambs to ingest cobalt per se.

This type of diet might be of great value in the production of cobalt deficiency in experimental lambs and should facilitate work being carried out on the physiological action of cobalt and other research on cobalt deficiency. 


\section{SUMMARY}

x. In-lamb ewes were fed a diet of 1 roo g. flaked maize, $250 \mathrm{~g}$. hay and $60 \mathrm{~g}$. mineral mixture daily for the last 3 months of pregnancy. This diet allowed of a daily ingestion of $0.0687 \mathrm{mg}$. cobalt. Their lambs when weaned at ro weeks of age were given $800 \mathrm{~g}$. flaked maize, $80 \mathrm{~g}$. hay, $25 \mathrm{~g}$. mineral mixture daily ( $0.0347 \mathrm{mg}$. cobalt), increasing steadily to the quantities in the ewe's diet at $\mathrm{I} 6$ weeks of age. These lambs all eventually showed the clinical signs of cobalt deficiency but made immediate dramatic response if fed to mg. cobalt/week.

2. Lambs given the same basal diet with a supplement of ro mg. cobalt from birth all gained weight normally.

3. The necessity for this type of experimentation in trace-element research is stressed.

4. The usefulness of a diet such as that described for the production of cobalt deficiency to facilitate work on the physiological action of cobalt and other research on cobalt deficiency is demonstrated.

The author gladly acknowledges his indebtedness to H. B. Turbert and D. Robertson, who were responsible for the accurate feeding and weighing of the experimental animals, and to Dr R. L. Mitchell, the Macaulay Institute for Soil Research, Aberdeen, for carrying out the spectrographic analysis of the foodstuffs.

\section{REFERENCES}

Bowstead, J. E. \& Sackville, J. P. (1939). Canad. F. Res., sect. C, r7, 15.

Bowstead, J. E., Sackville, J. P. \& Sinclair, R. D. (1941-2). Sci. Agric. 22, 314.

Filmer, J. F. \& Underwood, E. J. (1937). Aust. vet. F. 13, 57.

Marston, H. R. (1949). Proc. Specialist Conference in Agriculture, Australia.

Stewart, J. (1946). Scot. Agric. 26, 6.

Stewart, J., Mitchell, R. L. \& Stewart, A. B. (1941). Emp. Y. exp. Agric. 9, 145.

Woodman, H. E. (1948). Bull. Minist. Agric., Land., no. 48, p. 78. 